\title{
Ethical, Social and Legal Consequences of Genomic Medicine and Predictive Genetic Testing for Diabetes
}

\author{
Russell D'Souza \\ Head and Chair, Asia Pacific Division of the UNESCO Chair in Bioethics, Haifa. \\ Corresponding Author: Russell D'Souza \\ E-mail: russell.f.dsouza@gmail.com
}

\begin{abstract}
Genomics has contributed to a better understanding of many disorders including diabetes. The following article looks at the ethical, social and legal consequences of genomic medicine and predictive genetic testing for diabetes. This is currently a field in its nascent stage and developing rapidly all over the world. The various ethical facets of genomic medicine in diabetes like its effects on patient physician relationship, risk communication, genetic counseling and familial factors are explored and elucidated from a clinical, ethical, social and legal perspective.
\end{abstract}

Key words: diabetes, ethics, genomic medicine, personalised medicine

\section{INTRODUCTION}

Genomics has contributed greatly to our understanding of the molecular basis of disease and, to a lesser but growing extent, to the development of effective interventions. Clinicians and society at large, however, are concerned about the effect genetic knowledge will have on the well-being of individual persons and groups. Much effort is being devoted to trying to anticipate, understand, and address the ethical, legal, social, and political implications of genetics and genomics [1].

Understanding the social effects of genomics requires an analysis of the ways in which genetic information and a genetic approach to disease affect people individually, within their families and communities, and in their social and working lives. Genomics presents challenges with respect to clinicians' ethical and professional responsibilities, including the appropriate use of genomic information in the health care setting [1].

Genes affect virtually all human characteristics and diseases. These influences can be ascertained in individual patients through a review of the family history, physical examination, and the use of medical diagnostics [1]. Given the variety of these effects and the limits of knowledge, the term "genetic information" is used in various ways at different times. These various meanings may make sense in context, but confusion can occur requiring the speaker and listener are defining the term in the same way [1].

\section{What people in general are worried about}

The most commonly expressed fear is that genetic information will be used in ways that could harm people - for example, to deny them access to health insurance, employment, education, and even loans. Part of that concern is fuelled by the growing recognition that health information 
is not entirely private, despite people's expectations and desires to the contrary. This debate is informed appropriately by the recognition that limiting access to the medical record to the patient and the treating clinician is neither possible nor desirable [1].

People tend to see genetic information as more definitive and predictive than other types of data, human characteristics are the product of complex interactions over time between genes - both a person's own and those of other organisms - and the environment. It is felt, that the way to allay people's fears about genetics is simply to give them a more realistic understanding of the informative power of these tools. An approach to addressing the social implications of genetics requires knowledge, of how genes are perceived and what is known about their function [1].

\section{The Challenge of Genomic Medicine with respect to the Physician - Patient Relationship}

Consider the case of a man who died of colon cancer in the 1960s. When the same disease developed in his daughter approximately 25 years later, she obtained her father's pathology slides, discovered that he had had diffuse adenomatous polyposis coli, and sued the estate of her father's surgeon, alleging that the physician should have warned her about her 50 percent risk of having the disorder. An intermediate appellate court in New Jersey ruled that the physician had a duty to warn the daughter directly (she would have been a child at the time of her father's death), perhaps even over her father's objections.

This is only one court's view in one case, but given how much attention it received, it is important to ask whether this was a good result. Two central tenets of Western medicine are that physicians should focus on the interests of their patients and that they should protect the confidentiality of their patients' medical information. Yet the tools of genomic medicine often reveal information about health risks faced not only by patients but also by their relatives. What should clinicians do? It seems clear that they should tell their patients about the risks faced by family members. The harder questions are whether physicians are ethically permitted to contact the relatives themselves, in contravention of traditional patient-centred norms, and whether they should be legally required to do so.

This issue must be viewed in the light of the fact that the duty to protect confidentiality is not absolute. Physicians are required to report numerous infectious diseases, and they have been held liable for failing to warn people whom their patients have specifically threatened with violence. The question then becomes more complex: are genetic risks sufficiently similar to these existing exceptions to the requirement of confidentiality that they warrant an exception as well ? Over the years, numerous prominent advisory bodies have said no, opining that physicians should be permitted to breach confidentiality to warn third parties of genetic risks only as a last resort to avert serious harm [2].

\section{Diabetes}

Type 2 diabetes mellitus (T2DM) is a prevalent, chronic condition associated with extensive morbidity, decreased quality of life, and increased utilization of health services. $\stackrel{2}{2}$ The annual risk of developing T2DM for the average person living in the United States with normal glucose levels is approximately $0.7 \%$ per year [3].

The polygenic nature of T2DM has been a major challenge to identifying genes involved in the pathogenesis of this disease-knowledge that could give rise to new treatments and tests. However, following the completion of the Human Genome Project and HapMap and the development of high-throughput technologies, scientists are in a much better position to tackle the complex genetic underpinnings of T2DM [4]. The rise of genetic and genomic studies has aligned with the increasing incidence rate of T2DM A number of commercial tests have already been developed that assay a panel of genetic variants in several genes identified from genome-wide association studies of T2DM. Among the best studied of these are two very closely linked single nucleotide polymorphisms (SNPs) in the transcription factor 7-like 2 (TCF7L2) gene [5]. More than 20 studies have replicated the association between these two SNPs in TCF7L2 and increased T2DM risk. The largest pooled analysis reported an overall odds ratio of 1.37 with a single copy of the higher-risk allele at one of the TCF7L2 SNPs [6]. In comparison, individuals with a positive family history for T2DM are at a 2-6 times increased risk compared to those without a family history [7-10]. 
Unlike single-gene testing for Mendelian disorders that produce a relatively certain prediction of disease, genomic testing for complex diseases like T2DM will generate disease risk information. Some of the ethical issues of genome risk profiling or pre-dispositional testing overlap with singlegene testing used primarily for diagnosis, although additional issues related to pre-dispositional testing include challenges of communicating risk information (particularly low risks), uncertainty of disease risk and psychosocial impact of "at-risk" status and ensuring patient comprehension. Of substantial importance is that individuals are informed about these and other issues when they are deciding if the test is appropriate for them. Although written informed consent may not be warranted, a discussion with a physician or other professional such as a genetic counsellor can serve to educate and encourage careful consideration of the benefits and risks of testing as well as alternatives to testing. This article presents an overview of several issues that should be considered as genome risk profiling for T2DM becomes integrated into clinical care [11].

\section{Familial Implications}

As with any type of genetic testing, it is important to consider the impact of testing on family members. Predisposition testing for T2DM and other chronic diseases raises familial implications on two levels. The implication of test results for biological family members raises the issue of whether and how to discuss the results with other family members [12]. Tested individuals may be reluctant to share the results due to fear it will disrupt relationships, be hesitant of having to contact estranged and distant family members, and feel guilt [13-16]. Those who opt to share the results with family members may have difficulty accurately communicating the results [17-18] or minimize the seriousness of the finding [19]. Although a positive test result could be inferred from changes in lifestyle and preventive medical procedures, individuals undergoing testing should ascertain the wishes of other family members prior to discussing their test results [20]. Furthermore, as many individuals choose to undergo genetic testing for the sake of their children, they will need to understand when and how best to discuss the results with their children [2122]. Family members who decide to learn of their relative's results must also decide how they'll act upon them (e.g., getting themselves tested), if at all.

Second, given that environment can substantially influence risk for T2DM and other complex diseases, a positive result of one individual can affect the lifestyle of the entire family. For example, adoption of healthy eating habits may be better achieved if the entire family is involved in promoting healthy living [22-26]. Special treatment of a child found to be at increased genetic risk may lead to feelings of ostracism, stigmatization, and inferiority.

A related issue of the familial implications of genetic testing is the duty of physicians to disclose genetic test results to family members when their patient chooses not to do so. Studies have identified a subset of patients who declined to inform at-risk family members of their genetic test result [27-28]. In these situations, physicians may feel somewhat obligated to contact family members, although the practice is not common [28]. A handful of legal decisions have ruled that, under circumstances where a disease may be prevented, a physician has an obligation to warn relatives at risk [29-30]. Experts recommend physicians should encourage their patients to share test results with at-risk family members during the pre-test and post-test counselling sessions [3132]. The American Society of Human Genetics (ASHG) recommends that "the legal and ethical norm of patient confidentiality should be respected" and that the harms of nondisclosure must be weighed against breaching patient confidentiality [33]. It is unlikely that knowledge of the genetic risk of T2DM would satisfy the four ASHG criteria for disclosure, particularly the criterion of imminent harm [33].

\section{Risk Communication}

Communicating and understanding risk or probabilities has been an ongoing challenge for health professionals and patients, respectively. Misunderstanding genetic risks may lead to psychosocial harms or familial implications and significantly impact life decisions (e.g., family planning) [3437]. Unfamiliarity with genetic concepts and terminology as well as preconceived perceptions of personal and familial risk may pose barriers to understanding genetic test results [36]. For instance, 
individuals with a family history of heart disease did not always perceive themselves at increased risk since they felt "different" in crucial ways from affected relatives [38]. While there appears to be a tendency to overestimate risk for inherited cancers [39], some studies have found individuals who test positive underestimate their risk [40]. Furthermore, some individuals may interpret their risk as an absolute prediction of disease (fatalism), which may affect their likelihood to engage in preventive steps due to reduced perception of personal controllability to reduce disease risk [4143]. However, this does not appear to be a typical response [44], and often individuals will undergo genetic testing in order to gain a sense of control [45-46].

To maximize patient understanding, a combination of numeric, verbal, and pictorial approaches may be warranted to effectively communicate genetic risk [47]. The personal meaning of a test result is further framed by the ethnic and cultural environments of the individual and community [48-52]. Small to moderate risks revealed by testing can also pose a challenge to communication. Some patients may struggle with the concept of being "at risk" for a disease [53]. The concept of a singular, static general population ignores the fact that societies are highly diverse with different experiential influences and attitudes that can change over time [51, 54-56]. Therefore, health professionals will need to be sensitive to these additional factors that may influence patient understanding and application of risk information.

\section{Discrimination}

Genetic discrimination has been a long-standing concern regarding the use of genetic tests and participation in genetic research [57-59]. Although only a few cases of employment or health insurance discrimination have been documented [58], empirical evidence suggests the occurrence may be more widespread [60-61].

In 2008, the Genetic Information Non-discrimination Act (GINA) was signed into law [62-63], 13 years after the first federal bill was introduced to prohibit discrimination by health insurers or employers. Health insurers (group, individual, and Medicare issuers) are prohibited from adjusting premiums or contribution amounts, requesting or requiring an individual or a family member of an individual to undergo a genetic test, obtaining and using genetic test results in making a determination regarding payment, or requesting, requiring, or purchasing genetic information for underwriting purposes.

With some exceptions, employers are prohibited from using genetic information to discriminate against applicants or employees based on their genetic information (hiring, firing, or any personnel decisions), to "limit, segregate, or classify" employees on this basis, and to "request, require, or purchase genetic information with respect to an employee or a family member of an employee." Regulations will be developed by the appropriate federal agencies for implementation in 2009. As a majority of states have legislation prohibiting genetic discrimination by employers and health insurers, the new federal law will not pre-empt state laws with broader protections but rather will establish a minimum level of protection for all.

While GINA provides comprehensive protections against employment and health insurance discrimination, the law does not prohibit use of genetic information by long-term care, disability, and life insurers [66]. Given the range of complications and high mortality (seventh leading cause of death) of T2DM, individuals at risk for T2DM or other chronic diseases may consider purchasing or increasing their coverage provided by these groups [67]. In addition, the health insurance protections do not apply to members of the U.S. military or individuals who receive their health care through the Department of Veterans Affairs or Indian Health Service. Patients considering genetic testing should be informed of state and federal protections and be advised of noncovered groups.

\section{Appropriate Age of Genetic Testing}

Many professional groups strongly discourage genetic testing for children unless immediate clinical benefit can be gained [68-71]. Based on these guidelines, predictive testing for T2DM would likely be discouraged and testing delayed until adulthood. Potential harms include the risk of stigmatization, discrimination, and other adverse psychosocial impacts. However, several commercial genetic laboratories permit testing of children [72], providing an alternative option for 
parents interested in learning of their child's risks. Despite the absence of immediate clinical benefit in the prevention of T2DM, children may benefit by reducing their risk for a range of diseases from simple modifications to their lifestyle such as healthy eating and regular exercise and thereby maintain a healthy weight at a young age. Physicians should discuss the risks and benefits of testing children for T2DM with the entire family and, when possible, obtain the assent of the child.

\section{CONCLUSION}

As new predictive genetic tests for common, complex diseases such as T2DM are developed and commercialized, it will be critical to the safe and appropriate use of these new applications to consider the potential ethical implications they raise and steps to prevent or ameliorate harms. Although risk-based genetic testing for common diseases raise similar ethical issues to more traditional genetic testing for rare diseases, new challenges are raised due to the type of information revealed and access to tests. With thoughtful deliberation with health professionals, patients and families, test developers and laboratories, insurers and other stakeholders, these issues can be addressed to ensure the safe and appropriate use of these promising new clinical applications.

\section{REFERENCES}

1. American Diabetes Association. Economic consequences of diabetes mellitus in the U.S. in 1997. Diabet Care 1998;21(2):296-309.

2. Atlanta: U.S. Department of Health and Human Services. 2008. Centers for Disease Control and Prevention. National diabetes fact sheet: general information and national estimates on diabetes in the United States, 2007.

3. Centers for Disease Control and Prevention. Incidence of diabetes: crude and age-adjusted incidence of diagnosed diabetes per 1,000 population aged 18-79 years, United States, 19802007. http://www.cdc.gov/diabetes/statistics/incidence/fig2.htmAccessed October 2008.

4. O'Rahilly S, Barroso I, Wareham NJ. Genetic factors in type 2 diabetes: the end of the beginning? Science 2005;307(5708):370-3.

5. Freely associating. Nat Genet 1999;22(1):1-2.

6. Zeggini E, Weedon MN, Lindgren CM, Frayling TM, Elliott KS, Lango H, Timpson NJ, Perry JR, Rayner NW, Freathy RM, Barrett JC, Shields B, Morris AP, Ellard S, Groves CJ, Harries LW, Marchini JL, Owen KR, Knight B, Cardon LR, Walker M, Hitman GA, Morris AD, Doney AS. Wellcome Trust Case Control Consortium (WTCCC), McCarthy MI, Hattersley AT. Replication of genome-wide association signals in UK samples reveals risk loci for type 2 diabetes. Science 2007;316(5829):1336-41.

7. Hariri S, Yoon PW, Qureshi N, Valdez R, Scheuner MT, Khoury MJ. Family history of type 2 diabetes: a population-based screening tool for prevention? Genet Med 2006;8(2):102-8.

8. Brownson RC, Remington PL, Davis JR. 2nd ed. Washington DC: American Public Health Association; 1998. Chronic Disease Epidemiology and Control.

9. Harrison TA, Hindorff LA, Kim H, Wines RC, Bowen DJ, McGrath BB, Edwards KL. Family history of diabetes as a potential public health tool. Am J Prev Med 2003;24(2):152-9.

10. Valdez R, Yoon PW, Liu T, Khoury MJ. Family history and prevalence of diabetes in the US population: 6-year results from the National Health and Nutrition Examination Survey (NHANES, 1999 2004) Diabet Care 2007;30(10):2517-22.

11. Centers for Disease Control and Prevention. Crude and age-adjusted incidence of diagnosed diabetes per 1,000 population aged 18-79 years, United States, 19802006.http://www.cdc.gov/diabetes/statistics/incidence/fig2.htm.

12. Gaff CL, Clarke AJ, Atkinson P, Sivell S, Elwyn G, Iredale R, Thornton H, Dundon J, Shaw C, Edwards A. Process and outcome in communication of genetic information within families: a systematic review. Eur J Hum Genet 2007;15(10):999-1011.

13. Julian-Reynier C, Eisinger F, Vennin P, Chabal F, Aurran Y, Noguès C, Bignon YJ, MachelardRoumagnac M, Maugard-Louboutin C, Serin D, Blanc B, Orsoni P, Sobol H. Attitudes towards cancer predictive testing and transmission of information to the family. J Med Genet 1996;33(9):731-6.

14. Green J, Richards M, Murton F, Statham H, Hallowell N. Family communication and genetic counseling: the case of hereditary breast and ovarian cancer. J Genet Couns 1997;6(1):45-60. 
15. McInerney-Leo A, Biesecker BB, Hadley DW, Kase RG, Giambarresi TR, Johnson E, Lerman C, Struewing JP. BRCA1/2 testing in hereditary breast and ovarian cancer families II: impact on relationships. Am J Med Genet A 2005;133A(2):165-9.

16. Stoffel EM, Ford B, Mercado RC, Punglia D, Kohlmann W, Conrad P, Blanco A, Shannon KM, Powell M, Gruber SB, Terdiman J, Chung DC, Syngal S. Sharing genetic test results in Lynch syndrome: communication with close and distant relatives. Clin Gastroenterol Hepatol 2008;6(3):333-8.

17. Claes E, Evers-Kiebooms G, Boogaerts A, Decruyenaere M, Denayer L, Legius E. Communication with close and distant relatives in the context of genetic testing for hereditary breast and ovarian cancer in cancer patients. Am J Med Genet A 2003;116A(1):11-9.

18. Wagner Costalas J, Itzen M, Malick J, Babb JS, Bove B, Godwin AK, Daly MB. Communication of BRCA1 and BRCA2 results to at-risk relatives: a cancer risk assessment program's experience. Am J Med Genet C Semin Med Genet 2003;119C(1):11-8.

19. Ayme S, Macquart-Moulin G, Julian-Reynier C, Chabal F, Giraud F. Diffusion of information about genetic risk within families. Neuromuscul Disord 1993;3(5-6):571-4.

20. Daly MB, Barsevick A, Miller SM, Buckman R, Costalas J, Montgomery S, Bingler R. Communicating genetic test results to the family: a six-step, skills-building strategy. Fam Commun Health 2001;24(3):13-26.

21. Tercyak KP, Hughes C, Main D, Snyder C, Lynch JF, Lynch HT, Lerman C. Parental communication of BRCA1/2 genetic test results to children. Patient Educ Couns 2001;42(3):21324.

22. Tercyak KP, Peshkin BN, Demarco TA, Patenaude AF, Schneider KA, Garber JE, Valdimarsdottir $\mathrm{HB}$, Schwartz MD. Information needs of mothers regarding communicating BRCA1/2 cancer genetic test results to their children. Genet Test 2007;11(3):249-55.

23. Nader PR, Sellers DE, Johnson CC, Perry CL, Stone EJ, Cook KC, Bebchuk J, Luepker RV. The effect of adult participation in a school-based family intervention to improve children's diet and physical activity: the Child and Adolescent Trial for Cardiovascular Health. Prev Med 1996;25(4):455-64.

24. Cookson S, Heath A, Bertrand L. The HeartSmart Family Fun Pack: an evaluation of family-based intervention for cardiovascular risk reduction in children. Can J Public Health 2000;91(4):256-9.

25. Golan M, Weizman A. Familial approach to the treatment of childhood obesity: conceptual mode. J Nutr Educ 2001;33(2):102-7.

26. Kardia SL, Modell SM, Peyser PA. Family-centered approaches to understanding and preventing coronary heart disease. Am J Prev Med 2003;24(2):143-51.

27. Falk MJ, Dugan RB, O'Riordan MA, Matthews AL, Robin NH. Medical geneticists' duty to warn at-risk relatives for genetic disease. Am J Med Genet A 2003;120A(3):374-80.

28. Dugan RB, Wiesner GL, Juengst ET, O'Riordan M, Matthews AL, Robin NH. Duty to warn atrisk relatives for genetic disease: genetic counselors' clinical experience. Am J Med Genet C Semin Med Genet 2003;119C(1):27-34.

29. Pate v. Threlkel. 661 So.2d 278 (Fla. 1995)

30. Safer v. Estate of Pack. 677 A.2d 1188 (N.J. Super. Ct. App. Div. 1996)

31. Offit K, Groeger E, Turner S, Wadsworth EA, Weiser MA. The "duty to warn" a patient's family members about hereditary disease risks. JAMA 2004;292(12):1469-73.

32. Chan-Smutko G, Patel D, Shannon KM, Ryan PD. Professional challenges in cancer genetic testing: who is the patient? Oncologist 2008;13(3):232-8.

33. The American Society of Human Genetics Social Issues Subcommittee on Familial Disclosure. ASHG statement. Professional disclosure of familial genetic information. Am J Hum Genet 1998;62(2):474-83.

34. Fanos JH. The missing link in linkage analysis: the well sibling revisited. Genet Test 1999;3(3):2738.

35. Fanos JH, Johnson JP. Perception of carrier status by cystic fibrosis siblings. Am J Hum Genet 1995;57(2):431-8.

36. Saukko PM, Ellard S, Richards SH, Shepherd MH, Campbell JL. Patients' understanding of genetic susceptibility testing in mainstream medicine: qualitative study on thrombophilia. BMC Health Serv Res 2007; 7:82.

37. Harrison HF, Harrison BW, Walker AP, Lohman K, Ellis SD, Hall MA, Reiss J, Adams PC, Holup J, Acton RT, Bent T, Rivers C, Fadojutimi-Akinsiku M. Screening for hemochromatosis and iron overload: satisfaction with results notification and understanding of mailed results in unaffected participants of the HEIRS study. Genet Test 2008;12(4):491-500.

38. Hunt K, Emslie C, Watt G. Lay constructions of a family history of heart disease: potential for 
misunderstandings in the clinical encounter? Lancet 2001;357(9263):1168-71.

39. Croyle RT, Lerman C. Risk communication in genetic testing for cancer susceptibility. J Natl Cancer Inst Monogr 1999;25:59-66.

40. 40. Aktan-Collan K, Haukkala A, Mecklin JP, Uutela A, Kääriäinen H. Comprehension of cancer risk one and 12 months after predictive genetic testing for hereditary non-polyposis colorectal cancer. J Med Genet 2001;38(11):787-92.

41. Shiloh S. Illness representations, self-regulation, and genetic counseling: a theoretical review. J Genet Couns 2006;15(5):325-37.

42. DeVries H, Mesters I, van de Steeg H, Honing C. The general public's information needs and perceptions regarding hereditary cancer: an application of the Integrated Change Model. Patient Educ Couns 2005;56(2):154-65.

43. Frosch DL, Mello P, Lerman C. Behavioral consequences of testing for obesity risk. Cancer Epidemiol Biomarkers Prev 2005;14(6):1485-9.

44. Marteau T, Senior V, Humphries SE, Bobrow M, Cranston T, Crook MA, Day L, Fernandez M, Horne R, Iversen A, Jackson Z, Lynas J, Middleton-Price H, Savine R, Sikorski J, Watson M, Weinman J, Wierzbicki AS, Wray R. Genetic Risk Assessment for FH Trial Study Group. Psychological impact of genetic testing for familial hypercholesterolemia within a previously aware population: a randomized controlled trial. Am J Med Genet A 2004;128A(3):285-93.

45. Rose AL, Peters N, Shea JA, Armstrong K. Attitudes and misconceptions about predictive genetic testing for cancer risk. Commun Genet 2005;8(3):145-51.

46. Rose A, Peters N, Shea JA, Armstrong K. The association between knowledge and attitudes about genetic testing for cancer risk in the United States. J Health Commun 2005;10(4):309-21.

47. Lipkus IM. Numeric, verbal, and visual formats of conveying health risks: suggested best practices and future recommendations. Med Decis Making 2007;27(5):696-713.

48. Catz DS, Green NS, Tobin JN, Lloyd-Puryear MA, Kyler P, Umemoto A, Cernoch J, Brown R, Wolman F. Attitudes about genetics in underserved, culturally diverse populations. Community Genet 2005;8(3):161-72.

49. Bates BR, Lynch JA, Bevan JL, Condit CM. Warranted concerns, warranted outlooks: a focus group study of public understandings of genetic research. Soc Sci Med 2005;60(2):331-44.

50. Brunk CG. Public knowledge, public trust: understanding the "knowledge deficit. Community Genet 2006;9(3):178-83.

51. Cunningham-Burley S. Public knowledge and public trust. Community Genet. 2006;9(3):204-10.

52. Bates BR. Public culture and public understanding of genetics: a focus group study. Public Underst Sci 2005;14(1):47-65.

53. Scott S, Prior L, Wood F, Gray J. Repositioning the patient: the implications of being "at risk. Soc Sci Med 2005;60(8):1869-79.

54. Van der Sanden MCA, Meijman FJ. Dialogue guides awareness and understanding of science: an essay on different goals of dialogue leading to different science communication approaches. Public Understanding Sci 2008;17(1):89-103.

55. Wynne B. Public engagement as a means of restoring public trust in science-hitting the notes, but missing the music? Community Genet 2006;9(3):211-20.

56. Gottweis H. Gene therapy and the public: a matter of trust. Gene Ther 2002;9(11):667-9.

57. Baruch S, Hudson K. Civilian and military genetics: nondiscrimination policy in a post-GINA world. Am J Hum Genet 2008;83(4):435-44.

58. Hudson KL, Rothenberg KH, Andrews LB, Kahn MJ, Collins FS. Genetic discrimination and health insurance: an urgent need for reform. Science. 1995;270(5235):391-3.

59. Offit K, Thom P. Ethical and legal aspects of cancer genetic testing. Semin Oncol 2007;34(5):43543.

60. Secretary's Advisory Committee on Genetics, Health, and Society. Bethesda: Department of Health and Human Services; 2004. Public perspectives on genetic discrimination.http://oba.od.nih.gov/oba/sacghs/reports/Public_Perspectives_GenDiscrim.pdf.

61. Penziner E, Williams JK, Erwin C, Bombard Y, Wallis A, Beglinger LJ, Hayden MR, Paulsen JS. Perceptions of discrimination among persons who have undergone predictive testing for Huntington's disease. Am J Med Genet B Neuropsychiatr Genet 2008;147(3):320-5.

62. Public Law 110-233. Genetic Information Nondiscrimination Act of 2008

63. Slaughter LM. The Genetic Information Nondiscrimination Act: why your personal genetics are still vulnerable to discrimination. Surg Clin North Am 2008;88(4):723-38.

64. Hudson KL, Holohan MK, Collins FS. Keeping pace with the times-the Genetic Information Nondiscrimination Act of 2008. N Engl J Med 2008;358(25):2661-3.

65. Zick CD, Mathews CJ, Roberts JS, Cook-Deegan R, Pokorski RJ, Green RC. Genetic testing for 
Alzheimer's disease and its impact on insurance purchasing behavior. Health Aff (Millwood) 2005;24(2):483-90.

66. Centers for Disease Control and Prevention. Genetic testing for breast and ovarian cancer susceptibility: evaluating direct-to-consumer marketing -Atlanta, Denver, Raleigh-Durham, and Seattle, 2003. MMWR Morb Mortal Wkly Rep 2004;53(27):603-6.

67. Mouchawar J, Hensley-Alford S, Laurion S, Ellis J, Kulchak-Rahm A, Finucane ML, Meenan R, Axell L, Pollack R, Ritzwoller D. Impact of direct-to-consumer advertising for hereditary breast cancer testing on genetic services at a managed care organization: a naturally-occurring experiment. Genet Med 2005;7(3):191-7.

68. Mouchawar J, Laurion S, Ritzwoller DP, Ellis J, Kulchak-Rahm A, Hensley-Alford S. Assessing controversial direct-to-consumer advertising for hereditary breast cancer testing: reactions from women and their physicians in a managed care organization. Am J Manag Care 2005;11(10):6018.

69. Hogarth S, Javitt G, Melzer D. The current landscape for direct-to-consumer genetic testing: legal, ethical, and policy issues. Annu Rev Genomics Hum Genet 2008;9:161-82.

70. Goddard KA, Robitaille J, Dowling NF, Parrado AR, Fishman J, Bradley LA, Moore CA, Khoury MJ. Health-related direct-to-consumer genetic tests: a public health assessment and analysis of practices related to Internet-based tests for risk of thrombosis. Public Health Genomics. 2009;12(2):92-104.

71. American Medical Association. Genetic testing in children (Policy E-2.138). http://www.amaassn.org/ama/pub/physician-resources/medical-ethics/code-medical-ethics/opinion2138.shtml.

72. Borry P, Howard HC, Sénécal K, Avard D. Direct-to-consumer genome scanning services. Also for children? Nat Rev Genet 2009;10(1):8-16.

Acknowledgements - Nil

Source of Funding - Nil

Conflict of Interest - Nil 